\title{
Pollen of the Spermacoce (Rubiaceae) species from the Northern Territory of Australia: morphology and taxonomic significance
}

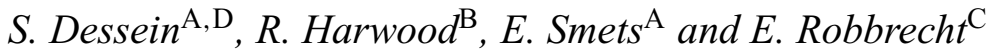 \\ ${ }^{A}$ Laboratory of Plant Systematics, Institute of Botany and Microbiology, K.U.Leuven, \\ Kasteelpark Arenberg 31, B-3001 Leuven, Belgium. \\ ${ }^{B}$ Northern Territory Herbarium, PO Box 496, Palmerston, NT 0831, Australia. \\ ${ }^{\mathrm{C}}$ National Botanic Garden of Belgium, Domein van Bouchout, B-1860 Meise, Belgium. \\ ${ }^{\mathrm{D}}$ Corresponding author. Email: steven.dessein@bio.kuleuven.ac.be
}

\begin{abstract}
Complementary to the revision of the genus Spermacoce in the Northern Territory of Australia, pollen morphology of 48 of the 53 native Spermacoce species from the Northern Territory has been investigated by scanning electron and light microscopy. There is considerable variation for most diagnostic pollen characters. The average equatorial diameter (E) ranges from 10.5 to $41.7 \mu \mathrm{m}$. Grains are invariably colporate with the apertures situated at the equator (being zonocolporate). The number of apertures varies from 3 to 17 . The endoaperture is generally an endocingulum, often with a secondary thinning at the ectocolpus; one species has endocolpi. The sexine is usually perforate, but psilate, foveolate, and (micro)reticulate patterns were also found. Supratectal elements are present as granules or microspines scattered over the whole surface or confined to a region around the ectoapertures. The inner nexine surface is granular, often with irregular grooves (endocracks).

The pollen morphological variation observed allows the distinction of four pollen types. Three of these types are not yet recorded in other palynological studies of Spermacoce. Pollen characters are often useful to delimit species and groups of related species.
\end{abstract}

\section{Introduction}

Numerous authors have acknowledged the value of pollen characters to unravel the phylogeny of Angiosperms. One of the first pollen morphological records for the family Rubiaceae is from Vermoesen (1922), who stressed the taxonomic importance of pollen features in the tribe Gardenieae. Bremekamp (1952) pioneered the use of pollen characters on a large scale to hypothesise relationships between genera as well as tribes of Rubiaceae. Subsequent studies dealing with the systematics of the family often included pollen morphological data (Verdcourt 1958; Lewis 1965; Bremekamp 1966).

With the more general use of scanning electron microscopy (SEM) to examine pollen grains, additional useful characters were discovered (e.g. endopatterns, special sexine patterns such as the double reticulum), and a few studies demonstrated the value of pollen data at tribal and generic level (e.g. Lobreau-Callen and Leroy 1980; Keddam-Malplanche 1985; Johansson 1987). In 'Tropical Woody Rubiaceae', a standard work for the Rubiaceae, Robbrecht (1988) gave a short summary of the pollen morphological variation within the family, being well aware that his survey was far from complete. In the subsequent years more and more systematic studies included pollen data and a few pollen treatments at the tribal level were published, for example Isertieae by Huysmans et al. (1998), Catesbaeeae-Chiococceae-Exostema complex by Huysmans et al. (1999) and Coccocypseleae by Piesschaert et al. (2000).

Most Rubiaceae have pollen grains with three apertures only. In the more derived clades of the family, however, we often notice an increase in the number of apertures. The herbaceous tribe Rubieae for example is characterised by 5-13-zonocolpate grains (Huysmans et al. 2003). In the Spermacoceae $s$. str., the clade to which Spermacoce L. belongs, pluricolporate pollen grains dominate, but 3 -colporate ones also occur. The genus Spermacoce is by far the most variable member of the alliance. This can partly be explained by the fact that it outnumbers the other genera in species, and that its pollen morphology is relatively well studied, but other well-documented, relatively large genera, such as Galianthe Griseb., show far less variation (Dessein 2003).

Pire (1996) and Dessein et al. (2002a) evaluated the value of pollen characters in the genus Spermacoce for the American and African representatives respectively. The two 
studies illustrate the extreme pollen morphological variation at species level. Prior to the present study, 17 different pollen types had been recognised within Spermacoce and many species can be identified based on their pollen grains only (cf. Dessein et al. 2002a, 2002b, 2003). Consequently, pollen is often useful in making taxonomic decisions at the species level.

Pollen of the Australian Spermacoce species has never been subjected to modern palynological research. The present paper partially fills this scientific gap by presenting the pollen morphology of the Australian Spermacoce species from the Northern Territory (NT); the study is complementary to the revision of these species by Harwood and Dessein (2005).

The following questions are addressed. (1) Does pollen morphology contribute to unravelling the systematic relationships between the species? (2) Is pollen of the Australian species different from pollen morphology of the other Spermacoce species? (3) Does the pollen morphological variation reflect functional adaptations?

\section{Material and methods}

This study is based on herbarium material from the Northern Territory Herbarium (DNA), with many duplicates deposited in the National Botanic Garden of Belgium (BR); 76 specimens from 48 species were investigated (for $S$. inaperta F.Muell., only observations in Hoyer medium were made, therefore it is not included in Table 2). The specimens investigated are listed in Table 1.

Most pollen data provided in this study are based on observations of acetolysed pollen grains, which were obtained by following Reitsma's 'wetting agent' method (Reitsma 1969). Since flowers and anthers of the study group are often rather small, $c$. ten mature flower buds were needed to yield enough pollen material. The buds were first hydrated in an Agepon solution $(1: 200)$. After dissection of the anthers and separation of the pollen grains from the remaining flower material by sifting with a micrometer sieve (diameter 60 or $90 \mu \mathrm{m}$ ), the pollen grains were dehydrated in pure acetic acid. The pollen grains were then acetolysed for $10 \mathrm{~min}$ in a heating block at approximately $90^{\circ} \mathrm{C}$. Pollen of some species (e.g. pollen type 1) were acetolysed for $8 \mathrm{~min}$ only. After acetolysis the sample from each specimen was split into two sub-samples, one part for light microscopic (LM) and the other for scanning electron microscopic (SEM) observations and storage. Pollen for SEM was rinsed in ethanol $70 \%$ or $96 \%$, pipetted on a stub, and left to dry. Prior to observations by SEM, the stubs were coated with gold with a SPI-MODULE ${ }^{\mathrm{TM}}$ sputter coater. Observations and digital images were made under a Jeol JSM 5800 LV microscope (JEOL-USA Inc., Peabody, MA).

Grains for LM studies were mounted in Kaiser's glycerin jelly and sealed with paraffin. The slides were observed using a Leitz Dialux 20 with a $\times 100$ oil immersion or $\times 40$ objective lens. Equatorial diameter (E) was measured under LM in at least ten mature pollen grains. It was often not possible to obtain accurate measurements of the polar axis (P) under LM, since many grains are suboblate and hence only visible in polar view. All other measurements were made on SE-micrographs with Carnoy software (Schols et al. 2002; http://www.kuleuven.ac.be/bio/sys/carnoy; verified 18 April 2005). To express the relative length of the colpi, the length colpi/polar axis ratio multiplied by $100(=\mathrm{LC} / \mathrm{P} \times 100)$ was used.

To investigate the inside of the pollen grains, the grains were broken by shaking a suspension of pollen and glass beads as described by Huysmans et al. (1994).
For $S$. inaperta flowering material was insufficient to allow acetolysis. Hydrated pollen grains were directly mounted on a slide and fixed with Hoyer's gum. Hoyer's gum was prepared as described by Robbrecht (1988); $30 \mathrm{~g}$ of Arabic gum was soaked in $50 \mathrm{~mL}$ distilled water, then $200 \mathrm{~g}$ chloral hydrate was added and the mixture stood for several days until it became clear, and then $20 \mathrm{~g}$ of glycerin was added.

Pollen terminology follows Punt et al. (1994).

\section{Results}

\section{Characters and character states}

This section provides the different character states observed for the important pollen features. The variation observed is then summarised in four pollen types, which are compared with the pollen types observed among African and American representatives of the genus in the discussion. Table 2 summarises the variation observed at species level.

\section{Polarity and symmetry}

Pollen of Australian Spermacoce species from the NT are all isopolar and radially symmetric.

\section{Size}

Pollen investigated is usually medium-sized (mean E between 30-40 $\mu \mathrm{m}$ ). Spermacoce brachystema R.Br. ex Benth., S. congestanthera Harwood, S. dolichosperma Harwood, S. graniticola Harwood, S. leptoloba Benth., S. lignosa Harwood, S. membranacea R.Br. ex Benth., S. platyloba Harwood, S. pogostoma Benth., S. reticulata Harwood, and $S$. rupicola Harwood, however, have small pollen grains (mean E-values ranging from 10.5 to $24.2 \mu \mathrm{m}$ ). The size variation is considerable, even within a single specimen, or between specimens of one single population, and often exceeds $20 \%$. A remarkable size variation has been observed in S. fabiformis Harwood: one specimen (Harwood 1034) has small pollen grains (mean $E=21.6 \mu \mathrm{m}$ ), while another collection (Harwood 837) has pollen grains that are almost double in size (mean $\mathrm{E}=38.2 \mu \mathrm{m}$ ).

Shape

Pollen shape in equatorial view is expressed by the ratio of the polar axis $(=\mathrm{P})$ and the equatorial diameter $(=\mathrm{E})$. For almost all species, the $\mathrm{P} / \mathrm{E}$-ratio varies between 0.88 and 1.14 , the pollen grains being spheroidal (e.g. Figs $3 C, E, 5 B, C$ ). Suboblate pollen grains (P/E between 0.75 and 0.88$)$ are found in e.g. S. pessima Harwood (Fig. 5A). Subprolate grains (P/E between 1.15 and 1.33) are observed in S. brachystema and $S$. dolichosperma (Fig. $1 F, G$ ), and sporadically in S. leptoloba, S. platyloba, S. reticulata, and S. rupicola. Oblate pollen grains $(\mathrm{P} / \mathrm{E}$ between 0.50 and 0.75$)$ are found in S. stenophylla F.Muell. (Fig. $2 B, I$ ) and $S$. inaperta. It should be noted, however, that the $\mathrm{P} / \mathrm{E}$ value is strongly influenced by the maturity of the pollen grains. Pollen grains that are not fully mature are often subprolate, while they are spheroidal 
Table 1. Specimens examined including pollen type and figure references

Specimens are housed in the Northern Territory Herbarium (DNA), often with duplicates at the National Botanic Garden of Belgium (BR)

\begin{tabular}{|c|c|c|c|}
\hline Species & Collection & Type & Figures \\
\hline S. aequabilis Harwood & Harwood 1037 & $20 \mathrm{c}$ & \\
\hline S. aurantiseta Harwood & Harwood 1072 & $20 c$ & $6 C$ \\
\hline \multirow[t]{2}{*}{ S. auriculata F.Muell. } & Harwood 612 & $20 c$ & $6 A, 7 D$ \\
\hline & Harwood 1071 & $20 c$ & \\
\hline S. brachystema R.Br. ex Benth. & Michell \& Carrow 1339A & 1 & \\
\hline \multirow[t]{3}{*}{ S. brevicilia Harwood } & Harwood 1091 & $20 c$ & \\
\hline & Harwood 781 & $20 c$ & \\
\hline & Harwood 1065 & $20 \mathrm{c}$ & $4 D$ \\
\hline \multirow[t]{2}{*}{ S. brevidens Harwood } & Harwood 1074 & $20 c$ & \\
\hline & Brennan 4286 & $20 c$ & \\
\hline \multirow[t]{6}{*}{ S. breviflora F.Muell. ex Benth. } & Harwood 852 & $20 c$ & \\
\hline & Harwood 619 & $20 c$ & \\
\hline & Harwood 1070 & $20 c$ & $6 D$ \\
\hline & Harwood 1056 & $20 c$ & \\
\hline & Harwood 618 & $20 c$ & \\
\hline & Harwood 555 & $20 c$ & \\
\hline \multirow[t]{4}{*}{ S. calliantha Harwood } & Harwood 1005 & $20 c$ & \\
\hline & Michell 2643 & $20 c$ & \\
\hline & Harwood 1031 & $20 c$ & $6 B, 7 B$ \\
\hline & Michell 2639 & $20 c$ & \\
\hline S. cardiophora Harwood & Lazarides 8002 & $20 c$ & \\
\hline S. caudata Harwood & Harwood 1160 & $20 \mathrm{c}$ & \\
\hline S. congestanthera Harwood & Harwood 1073 & $20 \mathrm{a}$ & $4 B, 5 D, 6 F$ \\
\hline S. constricta Harwood & Michell \& Yates 2180 & $20 c$ & \\
\hline S. discreta Harwood & Cowie 8252 & $20 c$ & \\
\hline \multirow[t]{2}{*}{ S. diversistyla Harwood } & Harwood 1154 & $20 \mathrm{a}$ & \\
\hline & Harwood 1179 & $20 \mathrm{a}$ & \\
\hline S. dolichosperma Harwood & Harwood 1066 & 1 & $1 F, G$ \\
\hline \multirow[t]{2}{*}{ S. elaiosoma Harwood } & Harwood 1156 & $20 c$ & \\
\hline & Harwood 807 & $20 c$ & \\
\hline \multirow[t]{2}{*}{ S. erectiloba Harwood } & Harwood 729 & $20 c$ & $4 A, 5 B$ \\
\hline & Harwood 812 & $20 c$ & \\
\hline S. erosa Harwood & Harwood 1153 & $20 c$ & \\
\hline S. erythrosepala Harwood & Harwood 1082 & $20 c$ & \\
\hline \multirow[t]{7}{*}{ S. fabiformis Harwood } & Harwood 1034 & $20 c$ & \\
\hline & Harwood 837 & $20 c$ & \\
\hline & Harwood 829 & $20 c$ & $7 E, F$ \\
\hline & Harwood 639 & $20 c$ & \\
\hline & Harwood 851 & $20 c$ & \\
\hline & Harwood 823 & $20 c$ & \\
\hline & Michell 2628 & $20 c$ & \\
\hline S. gilliesiae (Specht) J.R.Clarkson & Harwood 799 & $20 c$ & \\
\hline S. graniticola Harwood & Harwood 598 & 19 & $3 A-F$ \\
\hline \multirow[t]{2}{*}{ S. hillii (Chippend.) Govaerts } & Harwood 796 & $20 c$ & \\
\hline & Harwood 792 & $20 c$ & \\
\hline S. inaperta F.Muell. & Cowie \& Booth 6192 & 18 & \\
\hline S. juncta Harwood & Cowie 2873 & $20 c$ & \\
\hline S. laevigata F.Muell. & Harwood 1085 & $20 c$ & \\
\hline S. lamprosperma Harwood & Harwood 989 & $20 \mathrm{~b}$ & $5 C, 6 E, 7 C$ \\
\hline S. latimarginata Harwood & Harwood 789 & $20 c$ & \\
\hline S. leptoloba Benth. & Harwood 1036 & 1 & \\
\hline S. lignosa Harwood & Harwood 1151 & $20 c$ & \\
\hline S. membranacea R.Br. ex Benth. & Cowie 6547 & $20 c$ & \\
\hline S. occultiseta Harwood & Harwood 1030 & $20 c$ & \\
\hline \multirow[t]{2}{*}{ S. omissa J.R.Clarkson } & Harwood 1088 & $20 c$ & \\
\hline & Harwood 733 & $20 c$ & \\
\hline
\end{tabular}


Table 1. (continued)

\begin{tabular}{llcc}
\hline Species & \multicolumn{1}{c}{ Collection } & Type & Figures \\
\hline S. pessima Harwood & Cowie \& Dunlop 8484 & $20 \mathrm{c}$ & $5 A$ \\
S. phaeosperma Harwood & Harwood 609 & $20 \mathrm{c}$ & $4 C$ \\
S. phalloides Harwood & Harwood 594 & $20 \mathrm{c}$ & \\
S. platyloba Harwood & Harwood 1068 & 1 & \\
S. pogostoma Benth. & Harwood 1069 & 1 & $1 A, E$ \\
S. protrusa Harwood & Cowie 3599 & $20 \mathrm{c}$ & \\
S. redacta Harwood & Harwood 810 & $20 \mathrm{c}$ & \\
& Harwood 1041 & $20 \mathrm{c}$ & \\
S. reticulata Harwood & Michell 2627 & 1 & $1 C, D$ \\
S. retitesta Harwood & Harwood 786 & $20 \mathrm{c}$ & \\
S. rupicola Harwood & Harwood 830 & 1 & \\
& Harwood 600 & 1 & $1 B, H, I$ \\
S. scabrisina Harwood & Harwood 610 & $20 \mathrm{c}$ & \\
S. stenophylla F.Muell. & Harwood 552 & $20 \mathrm{c}$ & \\
S. suprahila Harwood & Egan 1936 & 18 & $2 A-E, H, I$ \\
S. tectanthera Harwood & Harwood 1035 & 18 & $2 F, G$ \\
S. trichosiphonia Harwood & Harwood 1083 & $20 \mathrm{c}$ & $7 A$ \\
\hline
\end{tabular}

or suboblate when they are fully mature. Furthermore, pollen grains that are not fully hydrated may also tend to be subprolate. It was also observed that pollen shape measured under LM differs slightly from the observations made under SEM. Pollen that is oblate spheroidal (P/E between 0.88 and 1) under LM often appears suboblate under SEM. This can partly be explained by the fact that suboblate pollen grains in the glycerin jelly will tend to orient their short polar axis perpendicular to the glass, and so these pollen grains will only be visible in polar view and cannot be used to determine the equatorial shape, while spheroidal pollen grains will be oriented in all directions. Consequently, the majority of pollen grains that are visible in equatorial view under LM are spheroidal.

In polar view, the pollen grains show a circular outline (e.g. Fig. $3 A, F)$, often somewhat lobed due to the sunken colpi (Fig. 4A-D). Spermacoce stenophylla and S. inaperta are the only exceptions, being triangular in outline (Fig. 2A, $H$ ).

\section{Aperture position}

The apertures are invariably situated at the equator. Pantoaperturate pollen grains as observed among African and American Spermacoce species are not present. In $S$. stenophylla and $S$. inaperta, the apertures are situated in the middle of the sides (planaperturate; Fig. $2 A, H$ ) when observed in polar view.

\section{Aperture type}

Pollen grains of all species investigated are colporate; the ectoaperture is invariably a colpus, the endoaperture an endocinglum (Figs 1I, 3E, 7A-C,F), except for S. stenophylla where an endocolpus is observed (Fig. $2 F, I$ ). Sometimes there is an additional thinning in the endocingulum at the ectocolpi (Fig. 7B, C). Where the ectoaperture and the endoaperture overlap, a gap is often observed in the colpus membrane.

The ectocolpi are slit-like and their relative length varies between approximately 30 in e.g. S. stenophylla and $S$. omissa J.R.Clarkson and approximately 75 in e.g. S. hillii (Chippend.) Govaerts and S. lamprosperma Harwood. $\mathrm{LC} / \mathrm{P} \times 100$ shows much variation within a single specimen; even on a single pollen grain short and long colpi have been observed.

\section{Aperture margo}

In $S$. brachystema, S. dolichosperma, S. graniticola, S. leptoloba, S. platyloba, S. pogostoma, S. reticulata, $S$. rupicola and $S$. stenophylla the sexine around the apertures is distinctly differentiated from the remainder of the sexine by the presence of supratectal elements (granules or microspines). These margines can be well delimited as in S. pogostoma (Fig. 1E) or rather vague as in S. dolichosperma (Fig. $1 F$ ). Spermacoce graniticola has a continuous girdle of supratectal elements at the equatorial zone (Fig. $3 C, D$ ). In other species, e.g. S. pessima, the perforations of the sexine bordering the apertures are larger than for the remaining sexine (Fig. 5A).

\section{Number of apertures}

The number of apertures ranges from three in S. stenophylla (Fig. $2 A, H), S$. inaperta, S. pogostoma (Fig. $1 A$ ), and S. rupicola to 17 in S. brevicilia Harwood. Most 


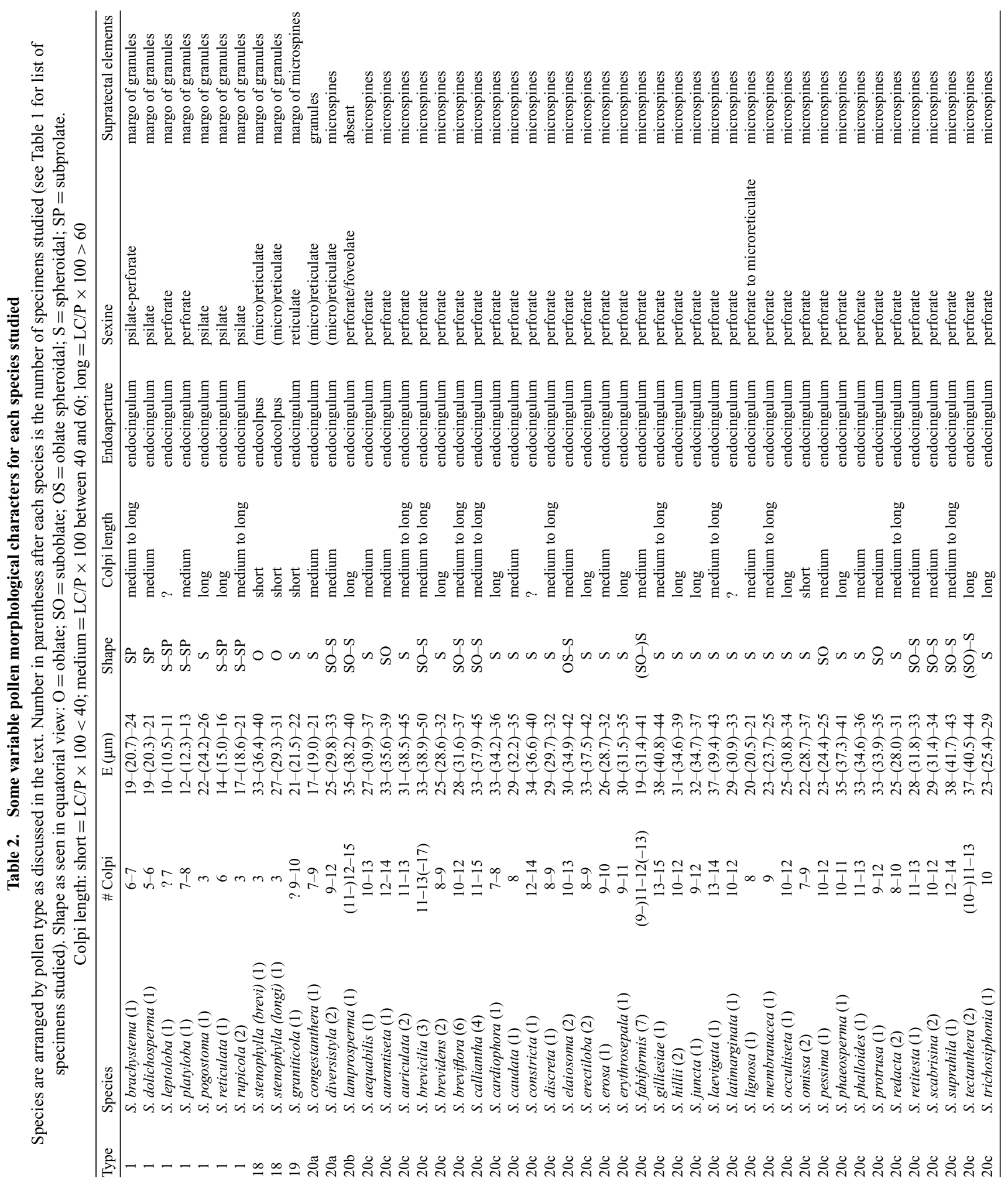



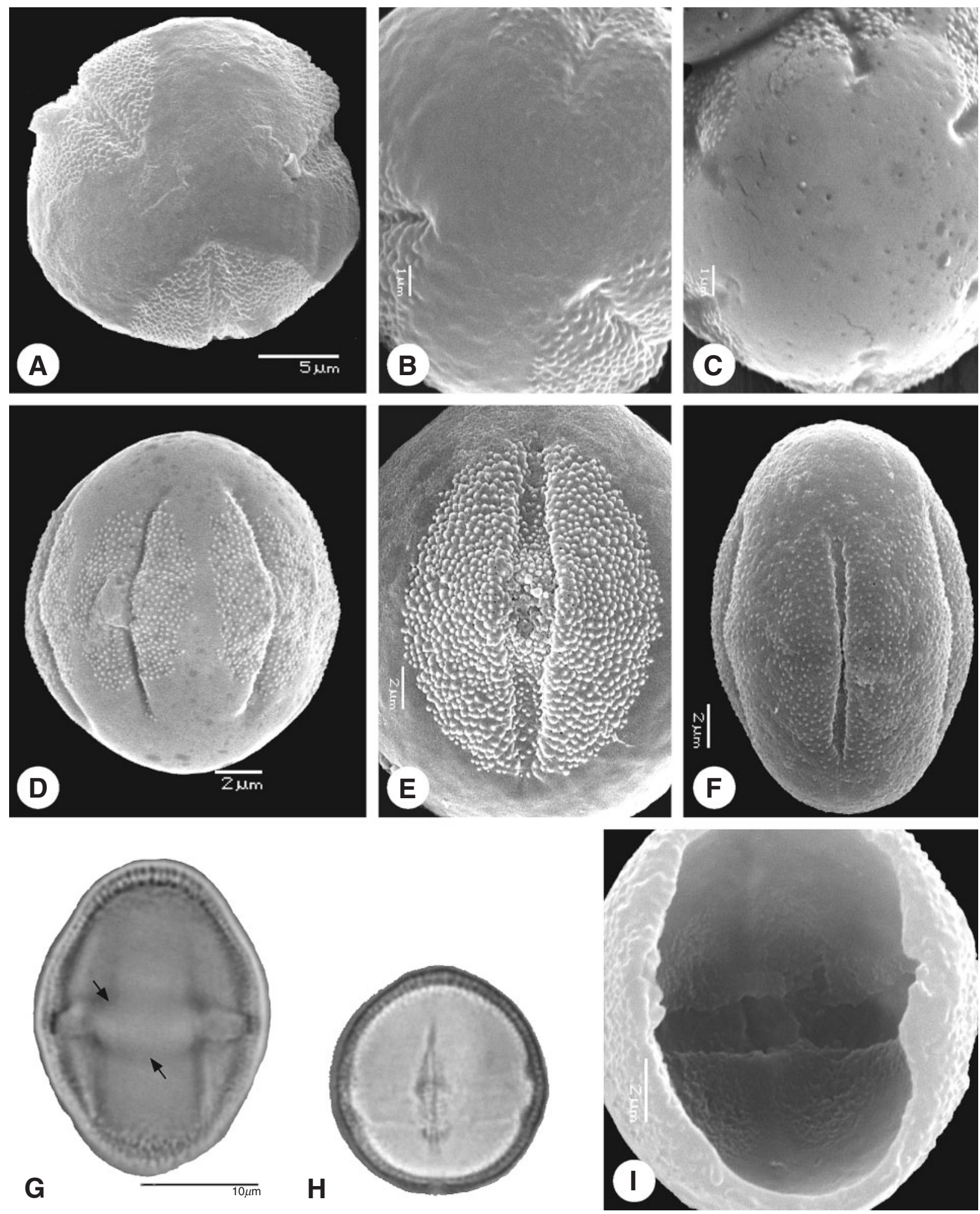

Fig. 1. SEM $(A-F, I)$ and LM $(G, H)$ photographs illustrating Type 1 pollen in NT species of Spermacoce. $(A) S$. pogostoma, polar view of 3-colporate pollen grain. $(B) S$. rupicola, detail of apocolpium of 3-colporate pollen grain. $(C, D) S$. reticulata: $(C)$ detail of apocolpium of 6-colporate pollen grain; $(D)$ equatorial view of pollen grain, notice the presence of granules around the ectoapertures. (E) S. pogostoma, detail of ectocolpus. $(F, G) S$. dolichosperma: $(F)$ equatorial view of pollen grain, notice the presence of granules around the ectoapertures; $(G)$ equatorial view of pollen grain, notice brighter zone indicating position of endocingulum (arrows). $(H, I) S$. rupicola: $(H)$ equatorial view of pollen grain; $(I)$ inner side of pollen grain showing endocingulum. 

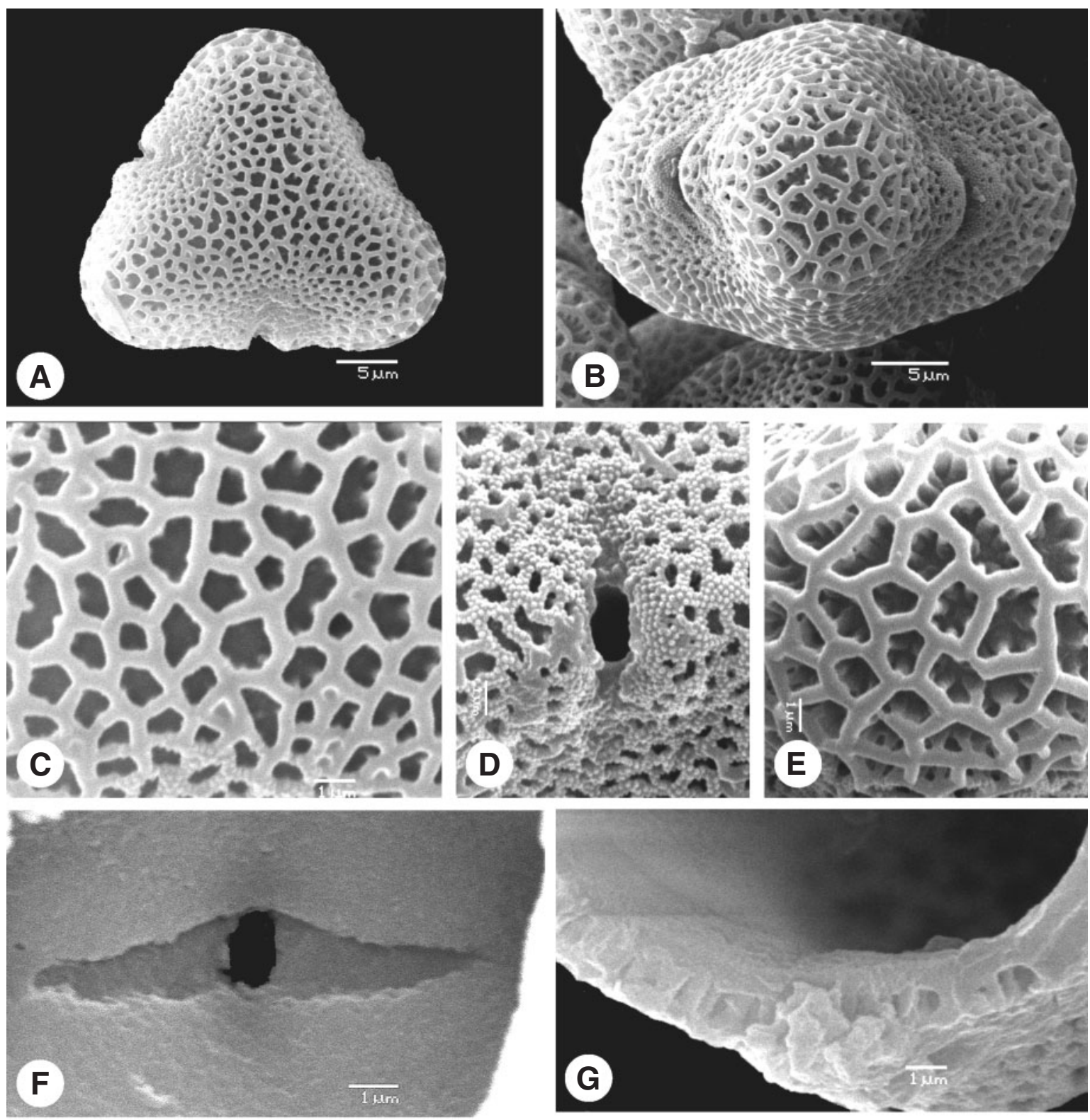

H
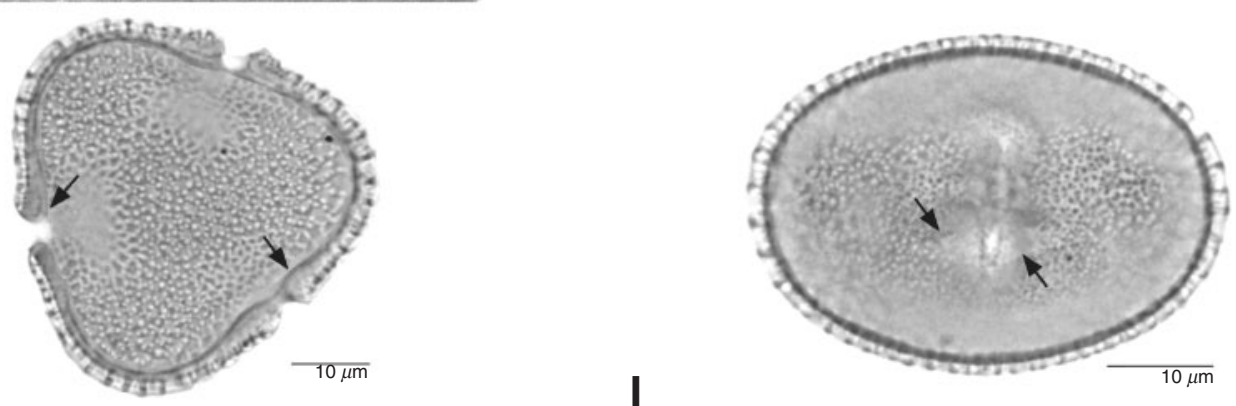

Fig. 2. SEM $(A-G)$ and LM $(H, I)$ photographs illustrating Type 18 pollen as observed in Spermacoce stenophylla. $(A)$ Polar view of 3-colporate pollen grain. $(B)$ Equatorial view of pollen grain. $(C)$ Detail of apocolpium showing reticulate sexine. $(D)$ Detail of ectocolpus, notice the presence of granules around the aperture. $(E)$ Detail of mesocolpium showing reticulate sexine. $(F)$ Detail of the inner side of pollen grain showing endocolpus. $(G)$ Detail of pollen wall. $(H)$ Polar view of pollen grain, notice the thickening of the nexine around the apertures (arrows). ( $I$ ) Equatorial view of pollen grain, notice the somewhat brighter zone perpendicular to the ectocolpus indicating the position of the endocolpus (arrows). 

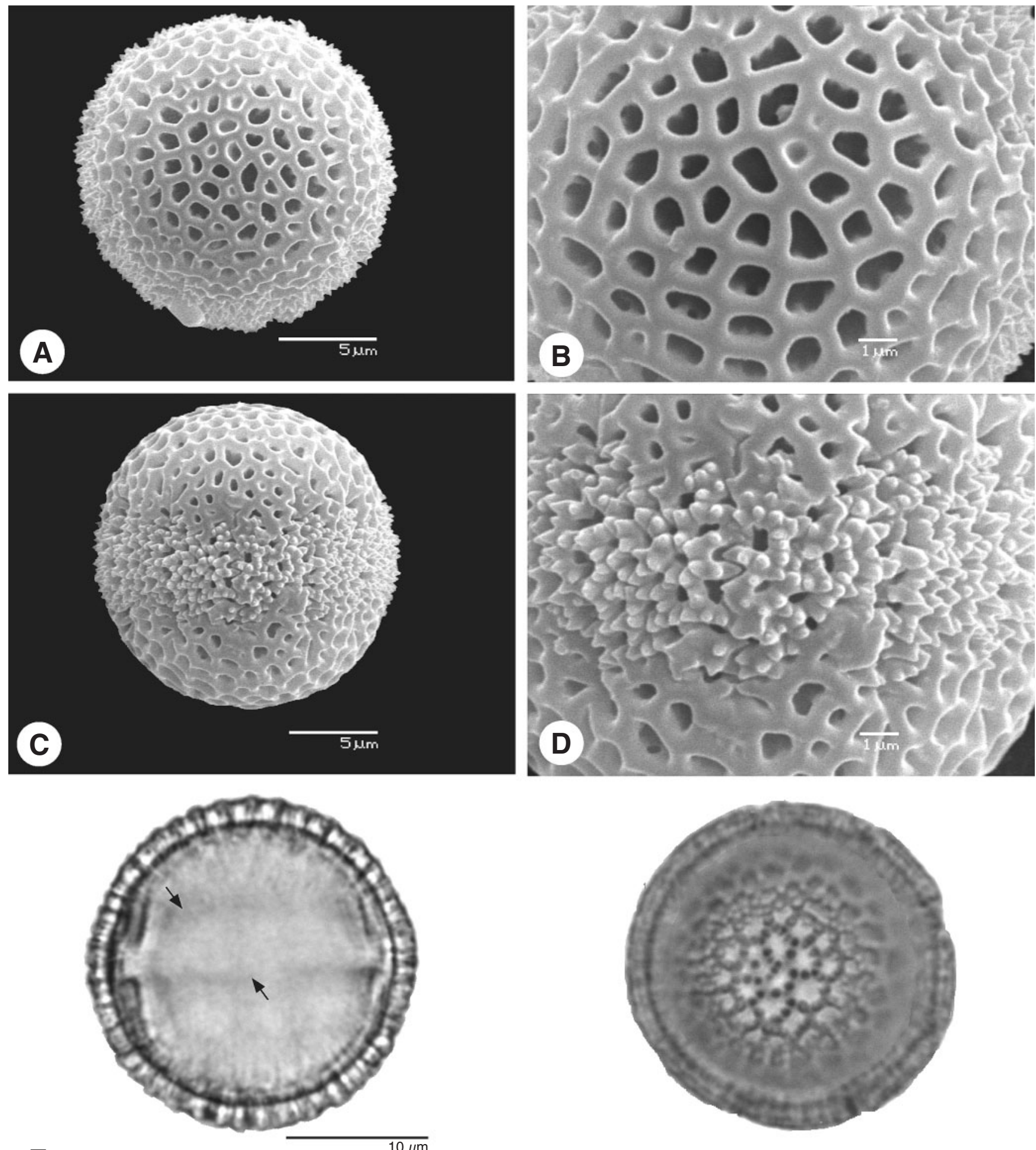

E

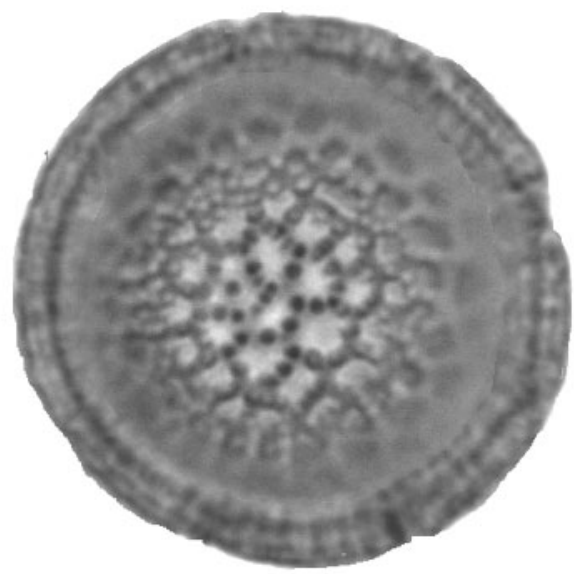

$\mathbf{F}$

Fig. 3. SEM $(A-D)$ and LM $(E, F)$ photographs illustrating Type 19 pollen as observed in Spermacoce graniticola. $(A)$ Polar view of pollen grain, notice that the ectoapertures are hardly visible. $(B)$ Detail of apocolpium showing reticulate sexine. $(C)$ Equatorial view of pollen grain, notice girdle of granules at the equator. $(D)$ Detail of equatorial zone. $(E)$ Equatorial view, notice the brighter zone indicating the presence of the endocingulum (arrows). $(F)$ Polar view of pollen grain. 

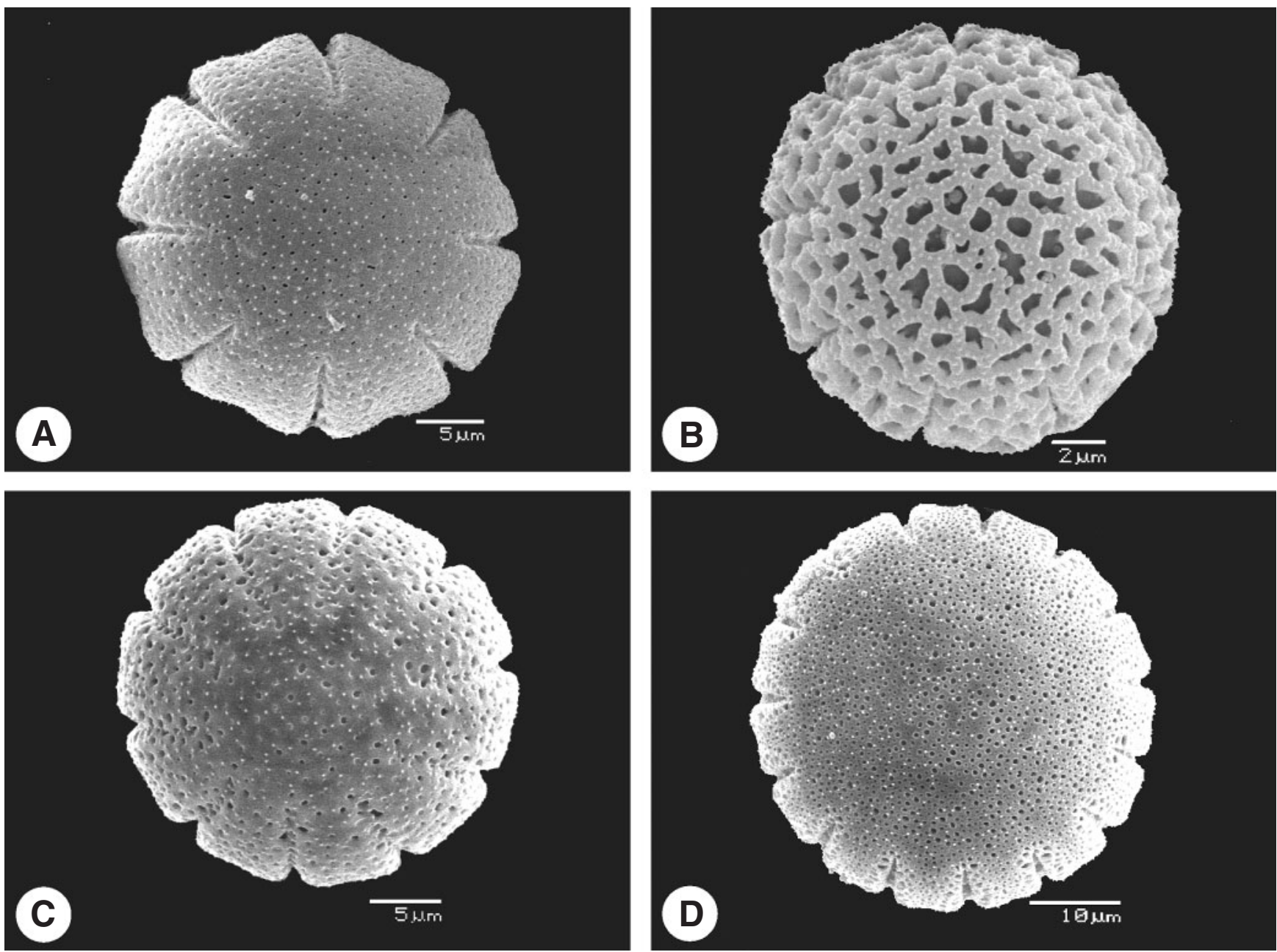

Fig. 4. SEM photographs illustrating variation in polar views of Type 20 pollen grains among NT species of Spermacoce. (A) S. erectiloba, polar view of 8-colporate pollen grain. (B) S. congestanthera, polar view of 9-colporate pollen grain. (C) S. phaeosperma, polar view of 10-colporate pollen grain. (D) S. brevicilia, polar view of 15-colporate pollen grain.

species have $10-13$ apertures. There is a positive correlation between the size of the pollen grains and the number of apertures $\left(r^{2}=0.38 ; P<0.01\right)$. This correlation was also found among pollen of the African Spermacoce species (Dessein et al. 2002a). The pollen grains of S. stenophylla are somewhat deviant: notwithstanding their large size, they have only three apertures.

The pluriaperturate condition is typical for the tribe Spermacoceae s. str., and is considered apomorphic within the family Rubiaceae. The variation in the number of apertures in individual species is rather limited (with the exception of $S$. brevicilia), which makes it a good taxonomic character at species level.

\section{Pollen wall stratification}

A nexine layer, a row of columellae, and a tectum with supratectal elements build up the exine (Figs $2 G, 7 D$ ). The thickness of the different layers varies strongly between pollen grains of a single specimen, but is also variable within a single grain. The nexine bordering the ectocolpi is often thickened (cf. Fig. $2 H$ ). In the apocolpium, the nexine varies between 0.44 and $1.07 \mu \mathrm{m}$, the columellae between 0.28 and $1.30 \mu \mathrm{m}$ and the tectum between 0.4 and 0.71 . Given the large intraspecific variation, the systematic value is limited.

\section{Tectum}

The tectum of most species is perforated (Fig. $6 A-C$ ), the perforations not exceeding $1 \mu \mathrm{m}$ in diameter, and the space between the perforations wider than the perforations. The perforations are rounded or somewhat angular, isodiametrical or irregular, rarely elongated, and larger perforations are often intermingled with smaller ones (Fig. $6 C, D$ ). There are only slight differences between the perforations of the apocolpium and those of the mesocolpia. As noted above, the perforations bordering the colpi, however, tend to be 

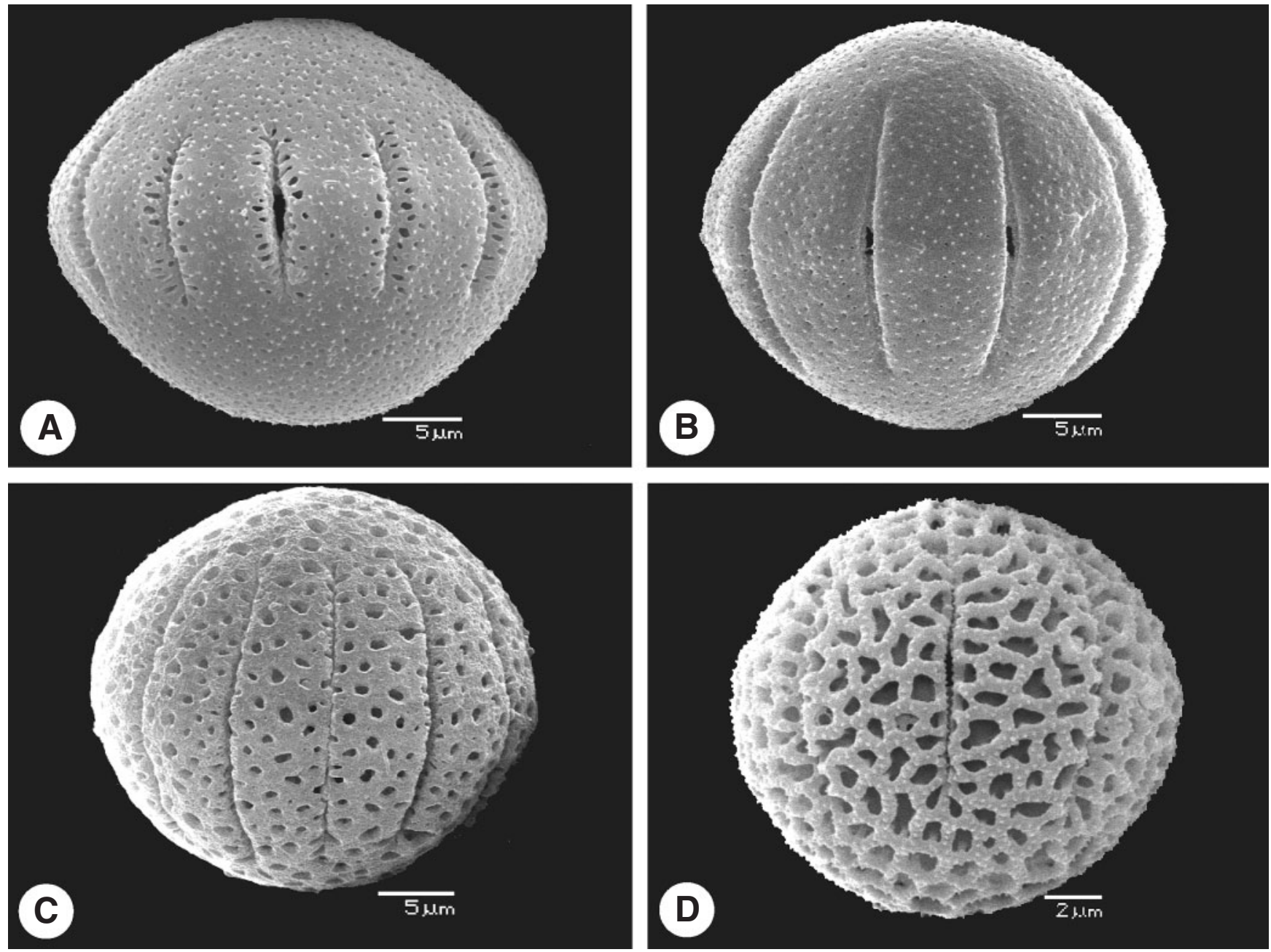

Fig. 5. SEM photographs illustrating variation in equatorial view of Type 20 pollen grains among NT species of Spermacoce. (A) S. pessima, equatorial view, notice the relatively short colpi and the larger perforations bordering the apertures. $(B) S$. erectiloba, equatorial view, notice the long colpi. (C) S. lamprosperma, equatorial view, notice the absence of granules. (D) $S$. congestanthera, equatorial view, notice the reticulate tectum with granules.

larger. In S. lamprosperma the tectum tends to be foveolate, in which perforations exceed $1 \mu \mathrm{m}$ but with muri wider than the perforations (Fig. 6E). In this species, the borders of the perforations show a distinct slope. Spermacoce diversistyla Harwood, $S$. congestanthera, $S$. graniticola, and S. stenophylla have a microreticulate to reticulate tectum in which the lumina are wider than the bordering muri (Figs $2 C-E, 3 B, 6 F$ ). Spermacoce lignosa Harwood has a tectum intermediate between perforate and microreticulate. Spermacoce brachystema, S. dolichosperma, S. pogostoma, $S$. reticulata, and $S$. rupicola apparently have few or no perforations at the smooth apocolpium (=psilate) (Fig. $1 B-C$ ).

\section{Supratectal elements}

At the apocolpium, most species have supratectal elements. These may be granules or microspines. The number of supratectal elements per $25 \mu \mathrm{m}^{2}$ varies from five to more than 30 and seems to be rather constant for a given species. More data are needed, however, to confirm this. Spermacoce lamprosperma lacks supratectal elements (Fig. $6 E$ ), while $S$. brachystema, S. dolichosperma, S. graniticola, S. platyloba, S. pogostoma, S. reticulata, S. rupicola and S. stenophylla only have supratectal elements around the ectoapertures.

\section{Endopatterns}

Two endopatterns can be described. The first type characterises most species and shows a granular nexine surface with narrowly triangular or linear shaped bands of thinned nexine at the mesocolpia. These bands usually connect to the endocingulum (Fig. $7 A-C, F$ ) and have regular (Fig. $7 A$ ) or irregular (Fig. $7 B, C$ ) margins. In between these extensions of the endocingulum, the nexine 

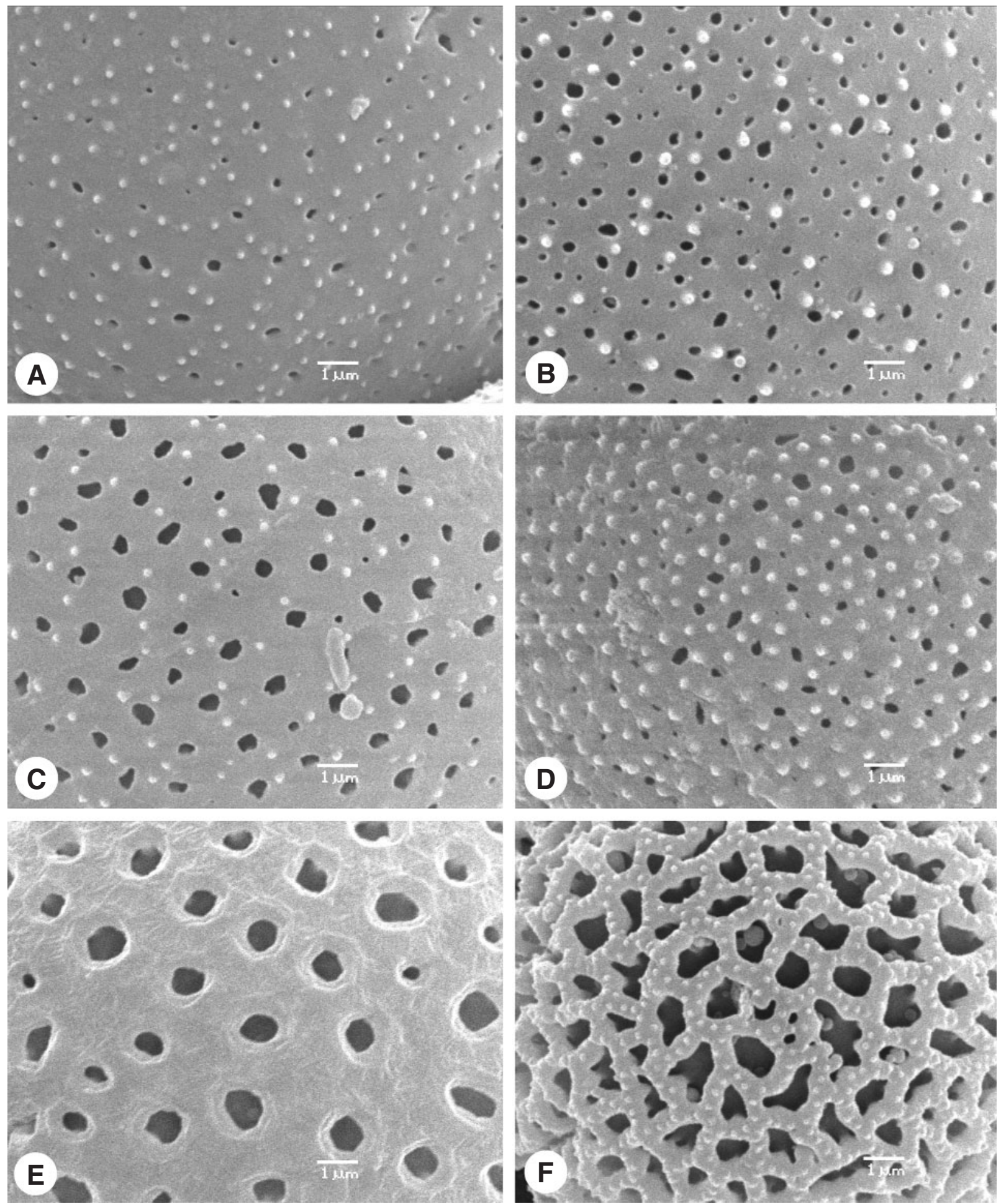

Fig. 6. SEM photographs illustrating variation in tectum of Type 20 pollen grains among NT species of Spermacoce. (A) S. auriculata, detail of apocolpium showing perforate tectum with small perforations and relatively densely beset with granules/microspines. (B) S. calliantha, detail of apocolpium showing perforate tectum with relatively large perforations and sparsely beset with microspines. (C) S. aurantiseta, detail of apocolpium showing perforate tectum with large perforations intermingled with smaller ones and sparsely beset with microspines. $(D) S$. breviflora, detail of apocolpium showing perforate tectum with large perforations intermingled with smaller ones and densely covered with microspines. (E) S. lamprosperma, detail of apocolpium showing foveolate tectum without supratectal elements. $(F) S$. congestanthera, detail of apocolpium showing reticulate tectum with the muri densely beset with granules/microspines. 

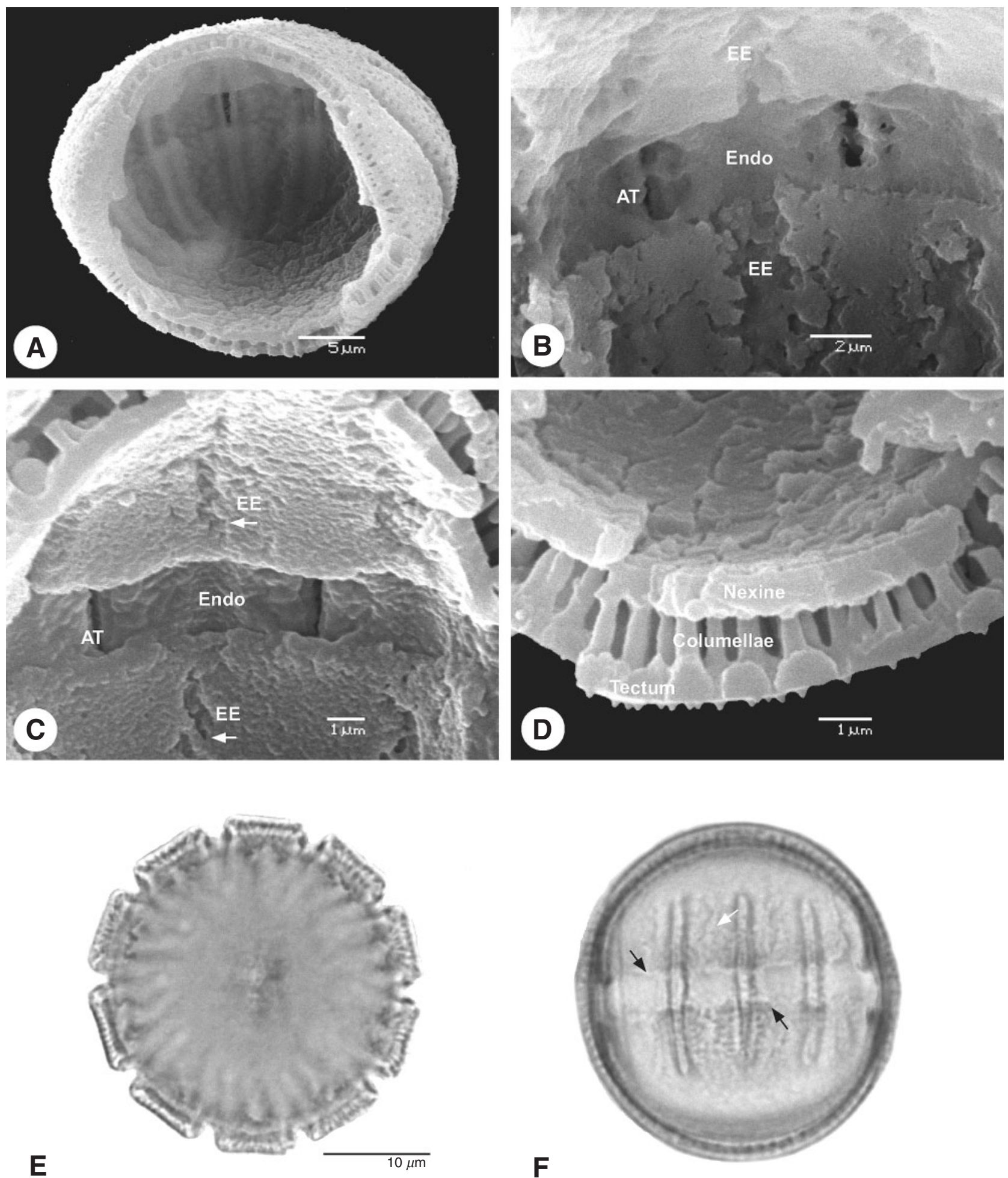

Fig. 7. SEM $(A-D)$ and LM $(E-F)$ photographs showing endopatterns observed among Type 20 pollen grains of NT species of Spermacoce. (A) S. suprahila, inside view of broken pollen grain showing endocingulum, extensions of endocingulum, and endocracks. (B) S. calliantha, detail of inside of pollen grain showing endocingulum (endo), additional thinning of endocingulum at the ectoapertures (AT), and irregular extensions of endocingulum in the mesocolpia (EE). (C) S. lamprosperma, detail of inside of pollen grain showing endocingulum with indistinct extensions in the mesocolpia. $(D) S$. auriculata, view at broken pollen wall showing nexine, a row of columellae and a perforated tectum with microspines. $(E, F) S$. fabiformis: $(E)$ polar view of pollen grain; $(F)$ equatorial view of pollen grain, notice the brighter zones indicating the position of the endocingulum (black arrows) and the extensions of the endocingulum (white arrow). 
is granular and mostly continuous, rarely with a few endocracks. At the apocolpium, the nexine is granular with numerous distinct endocracks (Fig. 7A). The second type has a continuous granular nexine, with no or obscure endocracks (Fig. 1I).

\section{Pollen types}

Four pollen types can be recognised amongst the NT species. One type is identical to Type 1 described by Pire (1996) and Dessein et al. (2002a). The three other pollen types have not yet been recorded in other palynological studies of Spermacoce, and as numbering of the pollen types continues from the previous studies (Pire 1996; Dessein et al. 2002a), these are indicated as Type 18, 19 and 20.

\section{Key to pollen types of Northern Territory species of Spermacoce}

1. Pollen triangular in polar view, 3-colporate; endoaperture an endocolpus Type 18

Pollen more or less circular in polar view, 3- or pluricolporate; endoaperture an endocingulum ...................................................... 2

2. Distinct margo of granules around ectoapertures; pollen small (mean

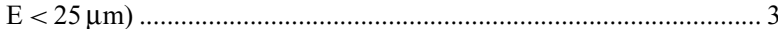

No distinct margo of granules, supratectal elements being absent or scattered over the whole pollen surface; pollen usually larger $\mathrm{E} \geq 25$,

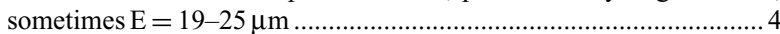

3. Tectum perforate or psilate at the apocolpium ............................. Type 1

Tectum reticulate at the apocolpium ........................................ Type 19

4. Tectum microreticulate to reticulate …………….................. Type 20a

Tectum perforate or foveolate ............................................................. 5

5. Tectum perforate to foveolate, without supratectal elements ....... Type 20b

Tectum perforate with supratectal elements ............................... Type 20c

Type 1 (Fig. 1)

Pollen 3-8-zonocolporate; mean E 10.5-24.2 $\mu \mathrm{m}$; equatorial shape spheroidal or subprolate; polar outline circular. Ectocolpi medium to long $(\mathrm{LC} / \mathrm{P} \times 100=45-70)$, slitlike, with a margo of granules. Endoaperture a narrow endocingulum without horns at the mesocolpia. Tectum perforate or ? psilate, supratectal elements absent from apocolpium. Inner nexine surface granular without distinct endocracks.

Species: S. brachystema, S. dolichosperma, S. leptoloba, S. platyloba, S. pogostoma, S. reticulata, S. rupicola.

\section{Remark}

This pollen type is also found among American and African representatives of Spermacoce, such as S. confusa, S. exilis, S. natalensis, S. ocymoides, and S. tenuior.

\section{Type 18 (Fig. 2)}

Pollen 3-zonocolporate and planaperturate; mean E 29.3-36.4 $\mu \mathrm{m}$; equatorial shape oblate; polar outline triangular. Ectocolpi short $(\mathrm{LC} / \mathrm{P} \times 100=c$. 30), slit-like, with a margo of granules, exine somewhat protruding around the ectoaperture due to thickened nexine. Endoaperture an endocolpus with acute ends. Tectum microreticulate to reticulate, supratectal elements absent from apocolpium. Inner nexine surface granular without distinct endocracks.

Species: S. stenophylla, S. inaperta.

\section{Type 19 (Fig. 3)}

Pollen ? 9-10-zonocolporate; mean E $21.5 \mu \mathrm{m}$; equatorial shape spheroidal; polar outline circular. Ectocolpi short $(\mathrm{LC} / \mathrm{P} \times 100=25-30)$, slit-like, with a margo of granules. Endoaperture a narrow endocingulum without extension horns. Tectum reticulate, supratectal elements absent from apocolpium. Inner nexine surface unknown.

Species: S. graniticola.

\section{Type 20 (Figs 4-7)}

Pollen 7-17-zonocolporate; mean E $19.0-41.7 \mu \mathrm{m}$; equatorial shape suboblate to spheroidal; polar outline circular. Ectocolpi relatively long ( $\mathrm{LC} / \mathrm{P} \times 100=40-75)$, sometimes shorter in S. omissa, slit-like, lacking margo of granules. Endoaperture a broad endocingulum with narrowly triangular or linear shaped extensions (of which the margins are distinct or rather diffuse) at the mesocolpia that are often continuous with the endocracks. Tectum perforate or more rarely (micro)reticulate with microspines uniformly present, rarely foveolate and lacking supratectal elements. Inner nexine surface granular with distinct endocracks at the apocolpium and granular without or with few endocracks in between the extensions of the endocingulum.

Based on differences of the tectum three subtypes can be described.

Type 20a: tectum microreticulate to reticulate with supratectal elements. Species: S. congestanthera, S. diversistyla.

Type 20b: tectum foveolate lacking supratectal elements. Specie: S. lamprosperma.

Type 20c: tectum perforate or somewhat microreticulate with supratectal elements. Species: S. aequabilis Harwood, S. aurantiseta Harwood, S. auriculata F.Muell., S. brevidens Harwood, S. brevicilia, S. breviflora F.Muell. ex Benth., S. cardiophora Harwood, S. calliantha Harwood, S. caudata Harwood, S. constricta Harwood, S. discreta Harwood, S. elaiosoma Harwood, S. erectiloba Harwood, S. erosa Harwood, S. erythrosepala Harwood, S. fabiformis, S. gilliesiae (Specht) J.R.Clarkson, S. hillii, S. juncta Harwood, S. laevigata F.Muell., S. latimarginata, S. lignosa, S. membranacea, S. occultiseta Harwood, S. omissa, S. pessima, S. phalloides Harwood, S. phaeosperma Harwood, S. redacta Harwood, S. retitesta Harwood, S. protrusa Harwood, S. scabrisina Harwood, S. suprahila Harwood, S. tectanthera Harwood, S. trichosiphonia Harwood. 


\section{Remark}

Pollen of $S$. omissa does not fully fit in this pollen type. Its colpi are relatively short $(\mathrm{LC} / \mathrm{P} \times 100=25-35)$ and the nexine is distinctly thickened towards the apertures. These differences are considered too small, however, to diagnose another pollen type.

\section{Discussion}

\section{Pollen of Australian v. African and American}

Spermacoce species

The pollen morphological variation observed among Australian Spermacoce species is considerable. The identification of four distinct pollen types in a group of only 48 species of one single genus is rather unusual within the family Rubiaceae, and even within angiosperms such variation is only sporadically observed. Compared with the pollen variation observed among African or American Spermacoce species, however, the variation is rather limited. From a similar number of African species, for example, nine pollen types were found (Dessein et al. 2002a).

Pollen type 1, characterised by small, often subprolate, pollen grains with a distinct margo of granules around the ectoapertures, is also found among African and American Spermacoce species. It was hypothesised (Dessein et al. 2002a; Dessein 2003) that this type of pollen grain could represent the basal pollen type within the genus Spermacoce. Indeed, this pollen type most resembles the pollen found in other Rubiaceae, and the other pollen types observed within the genus are easily derived from this type (cf. Pire 1996). Pollen types 19 and 20, exclusively found among Australian species, are also easily derived from this type. Pollen type 18 , however, is very atypical for the genus. The combination of the oblate equatorial shape, the relatively small dimensions, the short colpi, and the presence of endocolpi, has so far not been found in any other member of the genus.

\section{Systematic value}

Pollen morphology is a useful character in the systematics of the tribe Spermacoceae. Especially at the lower taxonomic levels (genera, subgenera, species) it often helps to delimit troublesome taxa, including some Australian taxa.

The informal groupings of species by Harwood and Dessein (2005) are partly supported by our pollen observations. All species of the 'basal' group (S. brachystema, S. dolichosperma, S. pogostoma, $S$. reticulata, and $S$. rupicola), characterised by small flowers with hairs inside near the base of the corolla lobes, and with the stigma and anthers included, possess Type 1 pollen grains. Pollen and DNA studies by Dessein (2003) suggest that this group of species is basal within the Australian clade, an opinion that is in agreement with the evolutionary pollen trends proposed by Pire (1996) and Dessein etal. (2002a). Within the 'basal' group,
S. pogostoma and S. rupicola are the only two species with three apertures. Spermacoce reticulata is at first sight very similar to $S$. rupicola, but differences in seed morphology set it apart. This is confirmed by pollen differences ( $\operatorname{six} v$. three colpi).

The 'linkage' group of Harwood and Dessein (2005) places together species with a mix of characters from the 'basal' group and those of the more derived groups. This is reflected in the pollen morphology, some species having primitive, others more derived pollen. Spermacoce leptoloba and $S$. platyloba have Type 1 pollen grains and feature the smallest grains of the study group. They are considered more closely related to each other than to any other species. Amongst other things, they are the only two species of this group with a persistent obturator on their seeds. Spermacoce graniticola is the only species with Type 19 pollen grains. This pollen type has a margo of microspines similar to what is observed in Type 1 pollen, but the colpi are short and the tectum is reticulate. Spermacoce graniticola differs from the species characterised by Type 1 pollen mainly by its exserted stamens. Spermacoce lignosa and S. membranacea possess Type 20 pollen grains.

The 'appendages', 'divided lobes', and 'appendages lost' groups of Harwood and Dessein (2005) are all characterised by pollen type 20 . All four species with divided corolla lobes (S. brevidens, S. cardiophora, S. caudata, S. erectiloba) have relatively few apertures (7-9). Spermacoce erectiloba has much longer lobes than the other three, and has the largest pollen grains. It is somewhat remarkable that this group hypothesised to be derived is characterised by relatively few apertures, a condition often related to more primitive taxa.

Pollen variation among the other species characterised by Type 20 pollen is not obviously related to any other important morphological characters (e.g. there is no relationship between pollen data and presence or absence of appendages, appendage type, seed coat surface, obturator persistent on seed or not).

Of the unplaced species, S. stenophylla and S. inaperta are characterised by pollen type 18 . They are closely related, having almost identical corollas. They differ in capsule dehiscence and seed type, but these differences have not been expressed in pollen. Their distinctive pollen type indicates that these species may have been isolated before the radiation of the other species took place. The presence of a margo of granules, a feature also present in Type 1 pollen, suggests that they evolved directly from an ancestor characterised by Type 1 pollen. The fact that this pollen type is found in two closely related species featuring a different fruit type- $-S$. stenophylla has capsules, while $S$. inaperta has schizocarps-demonstrates the danger of making taxonomic groupings based on fruit characters only. Two other unplaced species, $S$. congestanthera and S. omissa, have a somewhat special pollen morphology. The pollen of 
the former species is morphologically different in having a distinct (micro-)reticulate tectum, a feature also observed in $S$. diversistyla. Spermacoce congestanthera differs from the other NT Spermacoce species by its basifixed anthers and single linear stigma. Spermacoce omissa has a very different type of capsule dehiscence and its pollen differs from the typical Type 20 pollen grains by the much shorter colpi.

\section{How to explain this pollen morphological variation?}

It is difficult to estimate the functional aspects of the pollen morphological variation observed. In the following paragraphs an attempt is made, nevertheless, to point to some aspects that may or may not influence the different pollen characters.

\section{Pollen size}

Among the NT Spermacoce species, it appears that differences in pollen size do not always reflect functional adaptation. Relatively large pollen size variation is observed within a single specimen and between specimens of the same species. Several factors, including flower size, style length, pollen vector size, mineral nutrition, and water supply, may cause differences in pollen size (for an overview, see Muller 1979). For many Rubiaceae, pollen size variation is associated with heterostyly, in which the short-styled morph usually has larger pollen grains than the long-styled morph (Ganders 1979). The only Australian Spermacoce species that shows distinct heterostyly is $S$. multicaulis Benth., but this species is endemic to Queensland and not studied here. In S. stenophylla, the anthers may be overtopped by the style, but the opposite situation, anthers overtopping the style, is more common. This flower dimorphism is not comparable with other heterostylous species of the Rubiaceae because the anthers are invariably well exserted, and only the position of the style is variable. Pollen of both morphs was investigated and it turned out that pollen of the long-styled morph is larger than that of the short-styled morph (mean E $36.4 \mu \mathrm{m} v$. $29.3 \mu \mathrm{m}$ ), but comparable size variation is observed among genuine isostylous species, hence no sound conclusions can be drawn.

Size variation can also be attributed to the growth conditions of the specimens, with better conditions meaning larger grains (Muller 1979). This rule does not hold for the NT species. In species with both southern and northern collections, the southern collections often have larger pollen grains, but there are exceptions. The southern areas have less rainfall, and generally speaking, vegetation is not as dense or as tall. Following the rule of Muller (1979), you would expect the northern collections to have larger pollen grains. However, for S. fabiformis, the two most southerly collections have $\mathrm{E}$ values of 35-39 $\mu \mathrm{m}$ (Harwood 639) and 31-40 $\mu \mathrm{m}$ (Harwood 837), the most northerly collection 19-23 $\mu \mathrm{m}$ (Harwood 1034), and those in between (Harwood 829, 851, 823, Michell 2628) have a size in between; for $S$. hillii, the southern collection is $35-38 \mu \mathrm{m}$ (Harwood 792), and the northern collection 30-35 $\mu \mathrm{m}$ (Harwood 796); for S. stenophylla the southern collection is 33-40 $\mu \mathrm{m}$ (Egan 1936), the northern collection 27-31 $\mu \mathrm{m}$ (Harwood 1035); for S. auriculata the southern collection is $38-45 \mu \mathrm{m}$ (Harwood 612), and the northern collection 31-37 $\mu \mathrm{m}$ (Harwood 1071). Spermacoce omissa is a notable exception; the southern collection is 22-25 $\mu \mathrm{m}$ (Harwood 733), and the northern collection 29-37 $\mu \mathrm{m}$ (Harwood 1088). Spermacoce calliantha and S. breviflora, for both of which there are several collections over a large area to compare, do not show any pattern.

In Type 1 pollen grains, on the contrary, the small pollen size (mean E ranging from 10.5 to $24.2 \mu \mathrm{m}$ ) might be an adaptation to a specific pollinator. The species characterised by this pollen type have very short corolla tubes (often shorter than $1 \mathrm{~mm}$ ) and the anthers and style are included in the tube. In most other NT Spermacoce species the anthers and style are exserted, and it is possible that those species with short tubes and included anthers and style have different pollen vectors.

\section{Number of apertures}

The number of apertures is, as mentioned above, positively correlated with the pollen size. This is not surprising, since the larger the pollen grains the larger the surface where the colpi may initiate. Estimating the possible functional aspects of the number of colpi is difficult. More colpi may facilitate germination, but does the difference between 10 and 17 colpi really matter? Most probably it does not. A possible explanation may be found in the harmomegathic function of the colpi. Harmomegathy is the process by which pollen grains and spores change in shape to accommodate variations in the volume of the cytoplasm caused by changes in hydration. The invagination of the aperture membrane is known as an important harmomegathic mechanism (cf. Thanikaimoni 1986). It seems reasonable to assume that a larger volume requires more apertures to carry out this function.

\section{Aperture length}

The length of the apertures is rather variable within a single species. There is no direct evidence that it is an important feature, and it possibly also plays a role in the harmomegathic function of the pollen grains.

\section{Sexine ornamentation}

Variation in sexine ornamentation may indicate differences in pollinators. In general, psilate pollen grains are thought to be adapted to wind-pollination or beetles, while grains with a rough surface are typical for insect-pollinated species (cf. Punt 1986). Pollen of all Australian Spermacoce species is thought to be transported by insects. There are few data to show correlation between 
a certain sexine pattern and a pollinator, mainly because detailed observations are lacking. Grayum (1986) gives one of the best-documented examples: he found that among Araceae, beetles pollinate species with a psilate sexine, while species with spinose pollen grains are more often pollinated by flies.

\section{Summary}

The pollen morphology is important in the systematics of the Australian species of Spermacoce, particularly in defining many of them as distinct from African and American species and also in the clarification of groups of species. It is sometimes useful in distinguishing between morphologically similar species. The morphological variation exhibited by the pollen is poorly understood in relation to functional adaptation, primarily because little is known about pollination of the group.

\section{Acknowledgments}

We thank Marcel Verhaegen from the National Botanic Garden of Belgium for taking SEMs from the pollen grains, and Suzy Huysmans and an anonymous reviewer for the valuable comments on the first drafts of this manuscript. Steven Dessein is a postdoctoral fellow of the Fund for Scientific Research, Flanders (FWO-Vlaanderen). Financial support for this study was provided by project OT/01/25 from the Research Fund of the K.U.Leuven.

\section{References}

Bremekamp CEB (1952) The African species of Oldenlandia L. sensu Hiern et K. Schumann. Verhandelingen der Koninklijke Nederlandse Akademie van Wetenschappen, Afdeeling Natuurkunde, Tweede sectie 48, 1-297

Bremekamp CEB (1966) Remarks on the position, the delimitation and the subdivision of the Rubiaceae. Acta Botanica Néerlandica 15, $1-33$.

Dessein S (2003) 'Systematic studies in the Spermacoceae (Rubiaceae).' $\mathrm{PhD}$ thesis, Katholieke Universiteit Leuven, Belgium.

Dessein S, Huysmans S, Robbrecht E, Smets E (2002a) Pollen of African Spermacoce species (Rubiaceae): morphology and evolutionary aspects. Grana 41, 69-89. doi: 10.1080/001731302760156882

Dessein S, Jansen S, Robbrecht E, Smets E (2002b) A new species of Spermacoce (Rubiaceae) from the Manika high plateau (Katanga; R.D.Congo). Nordic Journal of Botany 2, 513-523.

Dessein S, Ntore S, Robbrecht E, Smets E (2003) Pollen and seeds reveal that Spermacoce thymoidea s.l. (African Rubiaceae, Spermacoceae) represents three endemic or disjunct species from the Zambesian high plateaus. Systematic Botany 28, 130-144.

Ganders FR (1979) The biology of heterostyly. New Zealand Journal of Botany 17, 607-635.

Grayum MH(1986) Correlations between pollination biology and pollen morphology in the Araceae with some implications for angiosperm evolution. In 'Pollen and spores: form and function. Linnean Society symposium series. Vol. 12'. (Eds S Blackmore, IK Ferguson) pp. 313-327. (Academic Press: London)

Harwood B, Dessein S (2005) Australian Spermacoce (Rubiaceae: Spermacoceae). I. Northern Territory. Australian Systematic Botany 18, 297-365.
Huysmans S, Robbrecht E, Smets E (1994) Are the genera Hallea and Mitragyna (Rubiaceae-Coptosapelteae) pollen morphologically distinct? Blumea 39, 321-340.

Huysmans S, Robbrecht E, Smets E (1998) A collapsed tribe revisited: pollen morphology of the Isertieae (CinchonoideaeRubiaceae). Review of Palaeobotany and Palynology 104, 85-113. doi: 10.1016/S0034-6667(98)00054-2

Huysmans S, Robbrecht E, Delprete P, Smets E (1999) Pollen morphological support for the Catesbaeeae-ChiococceaeExostema-complex (Rubiaceae). Grana 38, 325-338. doi: $10.1080 / 00173130050136118$

Huysmans S, Dessein S, Smets E, Robbrecht E (2003) Pollen morphology of NW European representatives confirms monophyly of Rubieae (Rubiaceae). Review of Palaeobotany and Palynology 127, 219-240. doi: 10.1016/S0034-6667(03)00121-0

Johansson JT (1987) Pollen morphology of the tribe Morindeae (Rubiaceae). Grana 26, 134-150.

Keddam-Malplanche M (1985) Le pollen et les stomates de Gardéniées (Rubiacée) du Gabon. Morphologie et tendances évolutives. Mémoires du Muséum national d'Histoire naturelle. Série B, Botanique 29, 1-109.

Lewis WH (1965) Cytopalynological study of African Hedyotideae (Rubiaceae). Annals of the Missouri Botanical Gardens 52, 182-211.

Lobreau-Callen D, Leroy JF (1980) Quelques données palynologiques sur le genre Coffea et autres genres du cercle des cafiers. In ' $9^{\mathrm{e}}$ colloque, London'. pp. 479-506. (Association Scientifique Internationale du Café: London)

Muller J (1979) Form and function in angiosperm pollen. Annals of the Missouri Botanical Gardens 66, 593-632.

Piesschaert F, Huysmans S, Jaimes I, Robbrecht E, Smets E (2000) Morphological evidence for an extended tribe Coccocypseleae (Rubiaceae-Rubioideae). Plant Biology 2, 536-546. doi: $10.1055 / \mathrm{s}-2000-7473$

Pire SM (1996) Palynological study of American species of Borreria (Rubiaceae-Spermacoceae). Opera Botanica Belgica 7, 416-423.

Punt W (1986) Functional factors influencing pollen form. In 'Pollen and spores: form and function. Linnean Society symposium series. Vol. 12'. (Eds S Blackmore, IK Ferguson) pp. 97-101. (Academic Press: London)

Punt W, Blackmore WS, Nilsson S, Le Thomas A (1994) 'Glossary of pollen and spore terminology.' (LPP Foundation: Utrecht)

Reitsma T (1969) Size modifications of recent pollen grains under different treatments. Review of Palaeobotany and Palynology 9, 175-202. doi: 10.1016/0034-6667(69)90003-7

Robbrecht E (1988) Tropical woody Rubiaceae. Characteristic features and progressions. Contributions to a new subfamilial classification. Opera Botanica Belgica 1, 1-272.

Schols P, Dessein S, D'hondt C, Huysmans S, Smets E (2002) Carnoy: a new digital measurement tool for palynology. Grana 41, 124-126. doi: $10.1080 / 001731302760156936$

Thanikaimoni G (1986) Pollen apertures: form and function. In 'Pollen and spores: form and function. Linnean Society Symposium Series. Vol. 12'. (Eds S Blackmore, IK Ferguson) pp. 119-136. (Academic Press: London)

Verdcourt B (1958) Remarks on the classification of the Rubiaceae. Bulletin du Jardin Botanique de l'État. Bruxelles 28 , 209-290.

Vermoesen C (1922) De fijnere structuur der stuifmeelkorrels en hunne systematische beteekenis bij de Angiospermen. Natuurwetenschappelijk Tijdschrift 4, 1-12.

Manuscript received 10 September 2003, accepted 6 April 2005 